CZASOPISMO INŻYNIERII LA¿DOWEJ, ŚRODOWISKA I ARCHITEKTURY JOURNAL OF CIVIL ENGINEERING, ENVIRONMENT AND ARCHITECTURE

JCEEA, t. XXXIII, z. 63 (4/16), październik-grudzień 2016, s. 201-208

Arkadiusz GUŻDA ${ }^{1}$

Norbert SZMOLKE ${ }^{2}$

\title{
POWIETRZNE POMPY CIEPŁA DO CIEPŁEJ WODY UŻYTKOWEJ Z WBUDOWANYM ZASOBNIKIEM WODNYM
}

\begin{abstract}
W pracy przedstawiono charakterystykę powietrznych pomp ciepła z zintegrowanym zasobnikiem wodnym do produkcji ciepłej wody użytkowej. Przedstawiono zasadę działania powietrznych pomp ciepła. Omówione zostały podstawowe elementy konstrukcyjne takie jak: sprężarki, skraplacze, parowacze oraz zawory regulacyjne. Przytoczono sprawności 28 urządzeń dostępnych na rynku europejskim, których współczynnik COP kształtował się w zakresie od 2,3 do 3,8. Średnia wartość COP wyniosła 3,1 .
\end{abstract}

Słowa kluczowe: efektywność, PN-EN 16147, współczynnik COP, elementy konstrukcyjne

\section{Wprowadzenie}

Ostatnimi czasy można zauważyć coraz większe zainteresowanie inwestorów odnawialnymi źródłami energii (OZE). Jest to związane ze wzrostem świadomości społeczeństwa, iż należy w mniejszym zakresie wykorzystywać konwencjonalne źródła energii zwiększając jednocześnie udział źródeł odnawialnych. Wykorzystywanie odnawialnych źródeł energii niesie za sobą wymierne korzyści ekologiczne i ekonomiczne. Zasada ta dotyczy również produkcji ciepłej wody użytkowej (CWU).

Jednym z przykładów alternatywnych systemów przygotowujących ciepłą wodę użytkową są pompy ciepła typu powietrze-woda $\mathrm{z}$ wbudowanym zasobnikiem wodnym. Są to urządzenia, które pozwalają na wykorzystanie ciepła niskotemperaturowego do celów przygotowywania ciepłej wody użytkowej. Zaintere-

\footnotetext{
1 Autor do korespondencji / corresponding author: Arkadiusz Gużda, Politechnika Opolska, Wydział Mechaniczny, Katedra Inżynierii Środowiska, ul. Prószkowska 76, 45-758 Opole; tel. 77 4498388; arkadiusz.guzda@gmail.com

${ }^{2}$ Norbert Szmolke, Politechnika Opolska, Wydział Mechaniczny, Katedra Inżynierii Środowiska, ul. Prószkowska 76, 45-758 Opole; tel. 77 4498391; n.szmolke@ po.opole.pl
} 
sowanie pompami ciepła wzrasta, co związane jest ze wzrostem cen paliw energetycznych, takich jak węgiel czy gaz ziemny.

Pompy ciepła są to urządzenia o zerowej emisji dwutlenku węgla do atmosfery. Działanie tych urządzeń polega na wykorzystaniu ciepła o temperaturze niższej w celu wytworzenia ciepła o temperaturze wyższej, które można spożytkować na przygotowywanie ciepłej wody użytkowej.

Proces podnoszenia temperatury wymaga doprowadzenia do rozpatrywanego układu energii napędowej. Rodzaj doprowadzonej energii zależy od rozwiązania konstrukcyjnego danej pompy ciepła; może to być energia elektryczna, mechaniczna czy też chemiczna [1].

Aby bliżej zobrazować proces przemian zachodzących w pompie ciepła, na rys. 1 przedstawiono wykres obiegu teoretycznego w układzie ciśnienie-entalpia właściwa p-h, charakterystyczny dla sprężarkowej pompy ciepła.

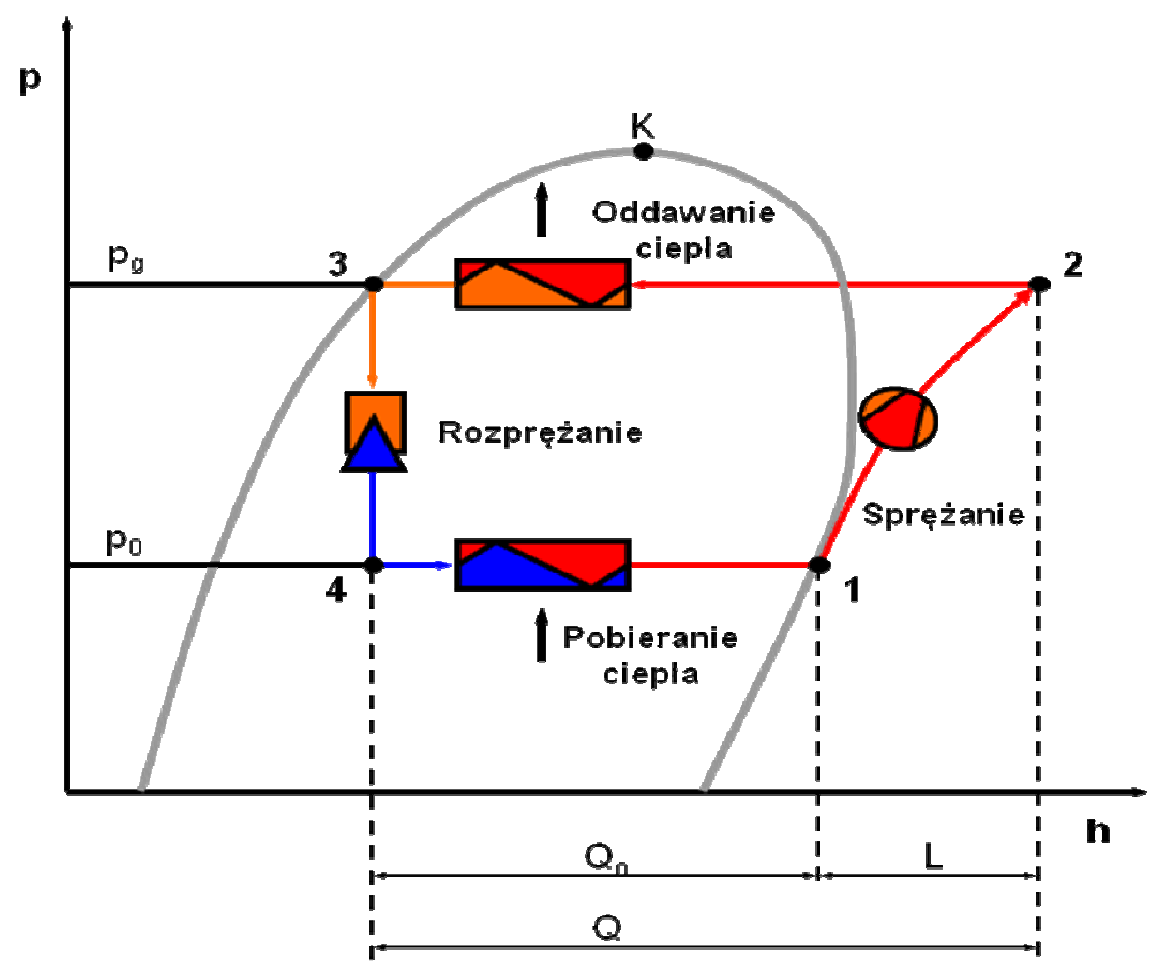

Rys. 1. Wykres obiegu teoretycznego p-h, gdzie: $\mathrm{Q}_{0}$ - ilość ciepła pozyskana w skraplaczu, $\mathrm{Q}$ - ilość ciepła pobrana w parowaczu, L - praca dostarczona do sprężarki

Fig. 1. Chart of the theoretical cycle p-h, where: $\mathrm{Q}_{0}$ - the quantity of heat produced in condenser, $\mathrm{Q}$ - the quantity of heat absorbed by the evaporator, L - work delivered to the compressor

Czynnik roboczy w stanie ciekłym wypływający ze skraplacza ulega rozprężeniu od ciśnienia $\mathrm{p}_{\mathrm{k}}$ panującego $\mathrm{w}$ skraplaczu do ciśnienia parowania $\mathrm{p}_{0}$ 
(punkt 3-4) w zaworze rozprężnym. Aby doszło do zmiany faz czynnika termodynamicznego (punkt 4-1), ciepło pobierane jest z dolnego źródła - powietrza atmosferycznego. Para, która wypływa z parownika ulega sprężeniu w sprężarce (punkt 1-2) do ciśnienia skraplania $p_{g}$; jest to możliwe dzięki doprowadzeniu do układu dodatkowej energii z zewnątrz. Następnie czynnik oddaje ciepło w skraplaczu (punkt 2-3), i cały proces zachodzi od początku.

Efektywność pracy urządzenia wyraża się współczynnikiem COP (ang. coefficent of performance) i wyraża się wzorem

$$
C O P=\frac{Q}{L}=\frac{Q_{O}+L}{L}=1+\frac{Q_{O}}{L}
$$

gdzie: $Q$ - ilość ciepła pobranego w parowaczu,

$Q_{0}$ - ilość ciepła pozyskana w skraplaczu,

$L$ - praca dostarczona do sprężarki.

Istotną rolę w procesie sprężania pełnią czynniki termodynamiczne, zwane również czynnikami roboczymi, gdyż to za ich pomocą można przetransportować ciepło z niższego na wyższy poziom temperatury; obecnie w pompach ciepła stosuje się najczęściej: R134a, R407c oraz R410A [2].

\section{Charakterystyka podstawowych elementów powietrznych pomp ciepła $\mathrm{z}$ wbudowanym zasobnikiem}

Do podstawowych elementów powietrznych pomp ciepła z zintegrowanym zasobnikiem wodnym możemy zaliczyć: sprężarki, skraplacze, parowacze, zbiorniki ciepłej wody użytkowej, urządzenia dławiące, presostaty i termostaty, urządzenia pomocnicze oraz zabezpieczające.

\subsection{Sprężarki}

Obecnie, w budowie pomp ciepła $\mathrm{z}$ zintegrowanym zasobnikiem wodnym najczęściej używane są sprężarki rotacyjne. W tego typu sprężarkach czynnik roboczy sprężany jest za pomocą ruchu obrotowego tłoka w cylindrze. Dzięki wykorzystaniu wirującego tłoka wyeliminowano układ korbowy, taka konstrukcja cechuje się zwartą budową i mniejszym hałasem.

Zasada działania polega na sprężaniu gazu dzięki wirującemu tłokowi, który jest osadzony mimośrodowo wobec cylindra. Łopatka, pod wpływem naporu sprężyny, przylega do powierzchni tłoka, dzieląc na dwie części przestrzeń w cylindrze sprężarki: ssawną i tłoczną. Działanie sprężarki rotacyjnej przedstawiono na rys.2. 


\subsection{Skraplacze}

Skraplacze w powietrznych pompach ciepła $\mathrm{z}$ wbudowanym zasobnikiem mają za zadanie skroplenie pary czynnika roboczego, czego następstwem jest uwolnienie energii, którą można spożytkować na podgrzanie wody w zbiorniku. W pompach ciepła powietrze-woda do produkcji ciepłej wody użytkowej najczęściej spotykane jest rozwiązanie ze skraplaczem wężownicowym, które przedstawiono na rys.3.

W tego typu rozwiązaniach współczynnik przenikania ciepła U skraplacza przyjmuje wartości na poziomie $200-250 \mathrm{~W} /\left(\mathrm{m}^{2} \cdot \mathrm{K}\right)$, ze względu na małą prędkość przepływu wody przez wymiennik [1].

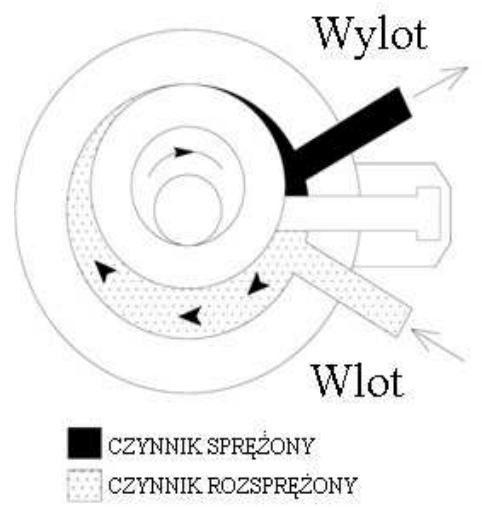

Rys. 2. Działanie sprężarki rotacyjnej [opracowanie własne]

Fig. 2. Diagram of a rotary compressor [own elaboration]

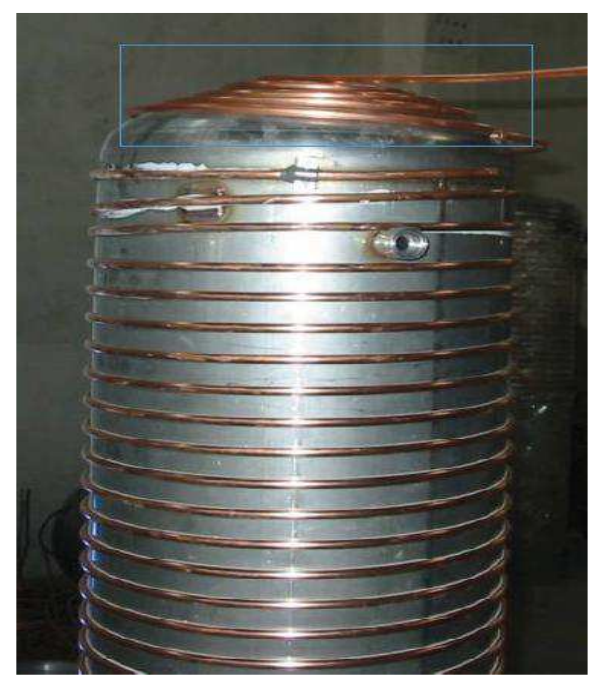

Rys. 3. Przykład skraplacza, na podstawie [3] Fig. 3. An example of condenser, based on [3]

\subsection{Parowacze}

Parowacze mają za zadanie pozyskanie ciepła z powietrza atmosferycznego i przekazanie go do wrzącego czynnika roboczego. W omawianych pompach ciepła konstrukcja parowacza składa się najczęściej z zespołu poziomych rur, połączonych kolektorami, w których następuje wrzenie czynnika. Przykład parowacza pokazano na rys.4. Ze względu na to, że w parowaczu następuje osuszanie powietrza rurki powinny być połączone równolegle, a ich zasilanie powinno odbywać się w sposób równomierny. Dzięki takiemu rozwiązaniu ogranicza się powstawanie szronu na rurkach parowacza; w przypadku oszronionej powierzchni rosną opory cieplne, co powoduje zmniejszenie współczynnika przenikania ciepła [1]. 


\subsection{Urządzenia regulacyjne}

Głównym zadaniem urządzeń regulacyjnych w pompach ciepła jest obniżenie ciśnienia czynnika chłodniczego, dopływającego do parowacza, w stosunku do ciśnienia panującego w skraplaczu. Ponadto mają one za zadanie regulować przepływ strumienia cieczy roboczej dopływającej do parownika w zależności od chwilowego obciążenia pompy ciepła.

W pompach ciepła do produkcji ciepłej wody użytkowej najczęściej używa się termostatycznych zaworów rozprężnych z zewnętrznym wyrównaniem ciśnienia, którego przykład pokazano na rys.5. Termostatyczny zawór rozprężny z zewnętrznym wyrównaniem ciśnienia posiada czujnik termometryczny zamontowany na przewodzie ssawnym za parowaczem. Dzięki rurce kapilarnej, której zadaniem jest przenoszenie zmian ciśnienia, spowodowanych przez temperaturę otoczenia czujnika na przeponie, możliwe jest napędzanie grzybka zaworu.

Na dolną stronę przepony działa ciśnienie zdławionego czynnika roboczego, dopływającego do parowacza. Poprzez wzrost przegrzania pary w przewodzie ssawnym sprężarki następuje wzrost siły działającej na przeponę. Wzrost ten powoduje zwiększenie stopnia otwarcia zaworu.

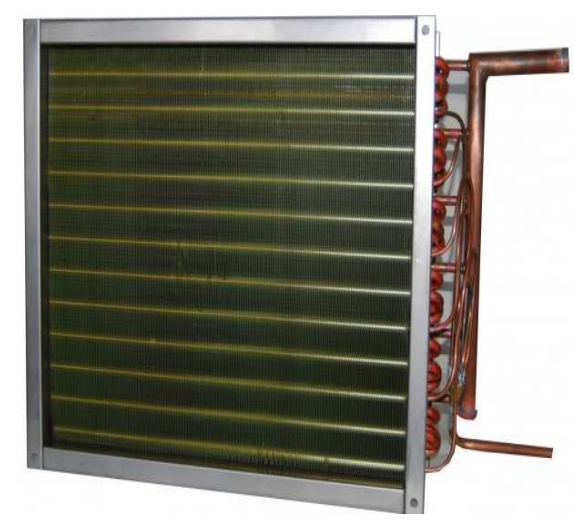

Rys. 4. Przykład parowacza, na podstawie [4]

Fig. 4. An example of evaporator, based on [4]

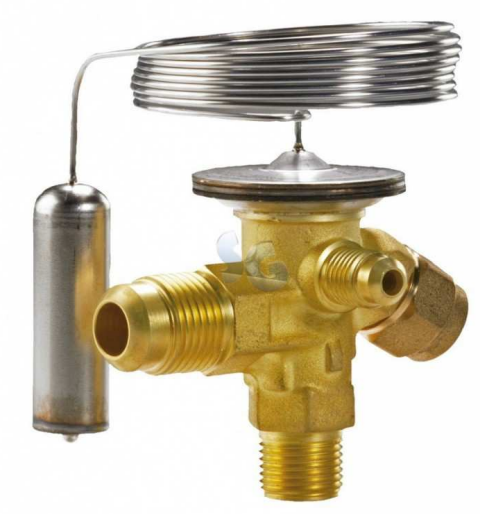

Rys. 5. Przykład termostatycznego zaworu rozprężnego, na podstawie [5]

Fig. 5. An example of thermostatic expansion valve, based on [5]

\section{Efektywność powietrznych pomp ciepła z wbudowanym zasobnikiem wodnym}

Pompa ciepła typu powietrze-woda $\mathrm{z}$ wbudowanym zasobnikiem wodnym może w samodzielny sposób pokrywać potrzeby użytkowników budynku jednorodzinnego na potrzeby przygotowania ciepłej wody użytkowej. 
Według obowiązującej normy PN-EN 16147 wskaźnik COP wyznacza się w trakcie cyklu pobierania (dziennego, określonego profilu poboru ciepłej wody użytkowej dla przeciętnego gospodarstwa domowego). Czas trwania takiego cyklu wynosi przynajmniej 24 godziny. Podczas jego przebiegu wykorzystuje się zdefiniowaną w normie [6] energię poboru CWU oraz wynikającą z pracy pompy ciepła energię dostarczoną [7].

Na podstawie wyników badań przeprowadzonych przez NTB Interstate University of Applied Sciences of Technology Buchs, przedstawionych w [8] dotyczących efektywności powietrznych pomp ciepła z zintegrowanym zasobnikiem; na rys. 6. zestawione zostały wyniki badań COP dla 28 pomp ciepła do produkcji ciepłej wody użytkowej, będących w ofercie producentów pomp na rynku europejskim. Wszystkie pompy ciepła zostały przebadane zgodnie z PNEN 16147:2011.

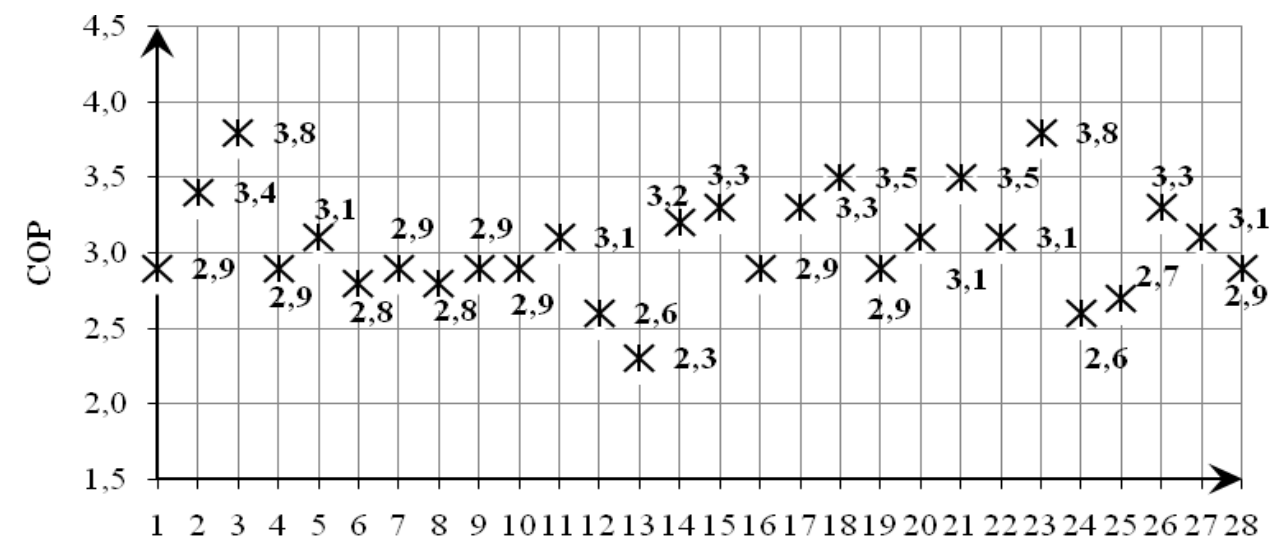

Numer badanej pompy

Rys. 6. Wyniki badań COP wybranych pomp ciepła, na podstawie [8]

Fig. 6. Test results of COP selected heat pumps, based on [8]

Analizując powyższy wykres, można zauważyć iż efektywność powietrznych pomp ciepła do produkcji ciepłej wody użytkowej jest różna. Waha się ona w granicach od 2,3 do 3,8. Natomiast wartość średnia oscyluje w granicy 3,1. W 25 przebadanych pompach ciepła zastosowano sprężarki rotacyjne. W pozostałych były to sprężarki spiralne, typu scroll (2 przypadki) oraz jedną sprężarkę tłokową. We wszystkich urządzeniach czynnikiem roboczym jest R134a. W tab.1 przedstawiono niektóre cechy konstrukcyjne oraz warunki pomiaru badanych pomp ciepła. 
Tabela 1. Cechy konstrukcyjne pomp ciepła i warunki pomiaru, na podstawie [8]

Table 1. Test principles and constructions features, based on [8]

\begin{tabular}{|c|c|c|c|c|}
\hline $\begin{array}{l}\text { Numer } \\
\text { pompy } \\
\text { ciepła }\end{array}$ & $\begin{array}{c}\text { Pojemność } \\
\text { czynnika }\end{array}$ & $\begin{array}{c}\text { Rodzaj powietrza } \\
\text { docierającego do } \\
\text { pompy ciepła }\end{array}$ & $\begin{array}{l}\text { Temperatura } \\
\text { dolnego źródła }\end{array}$ & Rodzaj sprężarki \\
\hline 1 & 1.10 & wewnętrzne & 15 & scroll \\
\hline 2 & 1.25 & wewnętrzne & 15 & rotacyjna \\
\hline 3 & 1.00 & wewnętrzne & 20 & rotacyjna \\
\hline 4 & 1.28 & wewnętrzne & 15 & rotacyjna \\
\hline 5 & 1.45 & wewnętrzne & 15 & rotacyjna \\
\hline 6 & 0.83 & wewnętrzne & 15 & rotacyjna \\
\hline 7 & 1.28 & wewnętrzne & 15 & rotacyjna \\
\hline 8 & 1.70 & zewnętrzne & 7 & rotacyjna \\
\hline 9 & 1.70 & zewnętrzne & 7 & rotacyjna \\
\hline 10 & 1.72 & zewnętrzne & 7 & rotacyjna \\
\hline 11 & 1.20 & wewnętrzne & 15 & rotacyjna \\
\hline 12 & 1.00 & zewnętrzne & 7 & rotacyjna \\
\hline 13 & 1.00 & wewnętrzne & 15 & tłokowa \\
\hline 14 & 0.90 & wewnętrzne & 15 & rotacyjna \\
\hline 15 & 0.90 & wewnętrzne & 20 & tłokowa \\
\hline 16 & 0.95 & wewnętrzne & 15 & rotacyjna \\
\hline 17 & 0.90 & wewnętrzne & 20 & rotacyjna \\
\hline 18 & 1.10 & wewnętrzne & 15 & rotacyjna \\
\hline 19 & 1.10 & wewnętrzne & 15 & rotacyjna \\
\hline 20 & 0.66 & wewnętrzne & 15 & rotacyjna \\
\hline 21 & 0.85 & wewnętrzne & 15 & rotacyjna \\
\hline 22 & 0.73 & wewnętrzne & 15 & rotacyjna \\
\hline 23 & 1.00 & wewnętrzne & 20 & rotacyjna \\
\hline 24 & 0.90 & zewnętrzne & 7 & rotacyjna \\
\hline 25 & 0.90 & wewnętrzne & 20 & rotacyjna \\
\hline 26 & 0.90 & wewnętrzne & 20 & rotacyjna \\
\hline 27 & 1.00 & wewnętrzne & 15 & rotacyjna \\
\hline 28 & 1.00 & zewnętrzne & 7 & rotacyjna \\
\hline
\end{tabular}

\section{Wnioski}

Pompy ciepła typu powietrze-woda $\mathrm{z}$ wbudowanym zasobnikiem wodnym, stanowią obecnie jedną z najtańszych alternatyw w produkcji ciepłej wody użytkowej. Omawiane w niniejszym artykule elementy konstrukcyjne tj. sprężarki, parowniki i zawory rozprężne są obecnie najczęściej stosowanymi w budowie powietrznych pomp ciepła do produkcji ciepłej wody użytkowej.

Dobór odpowiedniej sprężarki w pompie ciepła ściśle uwarunkowany jest wymaganą mocą cieplną urządzenia, liczby użytkowników oraz od rodzaju zastosowanego czynnik chłodniczego.

Ponadto, zaprezentowano wyniki badań współczynnika efektywności pracy pompy ciepła (COP) 28 urządzeń dostępnych na rynku europejskim. Współczynnik COP badanych urządzeń wahał się $\mathrm{w}$ granicy 2,3-3,8. Wszystkie badania przeprowadzono zgodnie z obowiązującą normą europejską PN-EN 16147.

W większości przypadków, w konstrukcji pomp ciepła zastosowano sprężarki rotacyjne, skraplacz w postaci rury nawiniętej na zbiornik , termostatycznego zawo- 
ru rozprężnego oraz parownika z poziomo ułożonymi rurami. Dokładne nazwy i typy urządzeń stanowią prywatną tajemnice firmy.

Efektywność pomp ciepła w omawianym badaniu, zależała również od warunków pomiaru tj. temperatury źródła ciepła. W większości przypadków efektywność podano dla temperatury rzędu $15^{\circ} \mathrm{C}$.

Podczas zakupu pompy ciepła warto zadać sobie trud i zapoznać się z opiniami na temat elementów konstrukcyjnych wybieranej pompy ciepła, gdyż okazać się może, że za niewielką dopłatą możemy zakupić urządzenie, w którym zastosowano elementy o zwiększonej trwałości i niezawodności.

\title{
Literatura
}

[1] Rubik M.: Pompy ciepła. Poradnik. Ośrodek Informacji "Technika instalacyjna w budownictwie", Warszawa 2006.

[2] Gużda A.: Wybrane czynniki robocze w pompach ciepła. Zeszyty Naukowe Politechniki Opolskiej, 2015, Mechanika z. 105, s.73-76.

[3] http://www.pompycieplacwu.pl/ \{dostęp 12.05.2016 r. \}.

[4] http:// www.juwent.com.pl/ \{dostęp 12.05.2016 r.\}.

[5] http://products.danfoss.pl/\{ dostęp 12.05.2016 r.\}.

[6] PN-EN 16147:2011 Pompy ciepła ze sprężarkami o napędzie elektrycznym - Badanie i wymagania dotyczące oznakowania zespołów do ogrzewania pomieszczeń i ciepłej wody użytkowej.

[7] Lachman P.: Co oznacza "pompa ciepła do przygotowywania c.w.u. klasy energetycznej A"?. Instal Reporter, 2014, IR nr 01, s. 15-18.

[8] WPZ-Bulletin, 08-2015, Information sheet of the Heat Pump Test Center WPZ in Buchs, Switzerland.

\section{AIR-WATER HEAT PUMP WITH INTEGRATED TANK FOR DOMESTIC HOT WATER}

\begin{abstract}
S u m m a r y
In this paper the characteristic of air-water heat pump with integrated tank for hot water purpose was described. The principle of operation of air source heat pump was presented. Furthemore, the basic construction elements such as: compressors, condensers, evaporators and the control valves was characterized. The principle operation of mentioned above elements used in air source heat pump with integrated tank was described. The paper presents the current norm EN 16147 for calculating the coefficient of performance of heat pumps for domestic hot water production. Moreover the efficiency of 28 devices available on the European market was presented. Whereas the coefficient of performance were in range from 2.3 to 3.8. The averaged value COP of the heat pumps were 3.1.
\end{abstract}

Keywords: efficency, PN-EN 16147, coefficient of performance, constructions elements

DOI:10.7862/rb.2016.264

Przestano do redakcji: $30.06 .2016 r$.

Przyjęto do druku: 20.12.2016r. 